\section{Star-gazing giant}

\section{Yerkes Observatory, 1892-1950: \\ The Birth, Near Death, and \\ Resurrection of a Scientific \\ Research Institution}

by Donald E. Osterbrock

University of Chicago Press: 1997. Pp. 384.

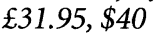

\section{Jack Meadows}

One enduring astronomical debate relates to the siting of observatories. On the one hand, they need clear skies; on the other, they must be accessible. As transport and communication facilities have improved, so sites have increasingly been chosen for the clarity of the night sky.

Yerkes Observatory was born towards the end of the nineteenth century at a crucial moment in this retreat from human habitation. When George Hale at the University of Chicago persuaded the millionaire Charles Yerkes to donate money to buy the largest telescope in the world, the university expected that the observatory would be built in the city. Persuasion by the astronomical community led to its erection out in the country, but at a low-lying site by Williams Bay in Wisconsin.

That period was also a time of transition in telescope design. The most favoured type of telescope in the nineteenth century had been the refractor. Yerkes' largest instrument was, correspondingly, a huge refracting telescope with a main lens 40 inches in diameter. But opinion was already coming around to the view that large telescopes in the future would be reflectors, using mirrors rather than lenses. So Yerkes occupies a transitional position between the nineteenth and the twentieth centuries as regards both site and equipment.
Donald Osterbrock's book covers the history of the observatory under its first three directors. A major theme is how they variously coped with the astronomical environment that the site and equipment provided. The first director, Hale, did not stay long. By 1904, he had migrated to California, where he subsequently erected a large reflecting telescope on the top of Mount Wilson, correctly foreseeing the way in which observational astronomy would develop in the twentieth century.

Hale left Edwin Frost as his successor at Yerkes. As Osterbrock shows well, Frost was a charming man, but had little of Hale's pioneering spirit. The research activities of the observatory slid slowly downhill during the three decades of his reign.

Frost's successor, Otto Struve, a Russian émigré from a distinguished astronomical family, was much more in the Hale mould. $\mathrm{He}$ developed joint activities with the new McDonald Observatory in Texas which allowed staff at Yerkes regular access to a large reflecting telescope on a mountain top. This proved a good way of overcoming the limitations of the Yerkes site.

More importantly, Struve pressurized the University of Chicago into supporting a remarkable mix of outstanding theoretical and observational astrophysicists. For a time, immediately before and after the Second World War, Yerkes became one of the most exciting places in the world for astrophysical research.

These central chapters of the book are among the most interesting. Osterbrock's extensive use of archival material makes plain how difficult it was for such a group of prima donnas to remain in harness together. Struve's choice of staff was triumphantly vindicated - Chandrasekhar, for example, became one of the first astrophysicists to win

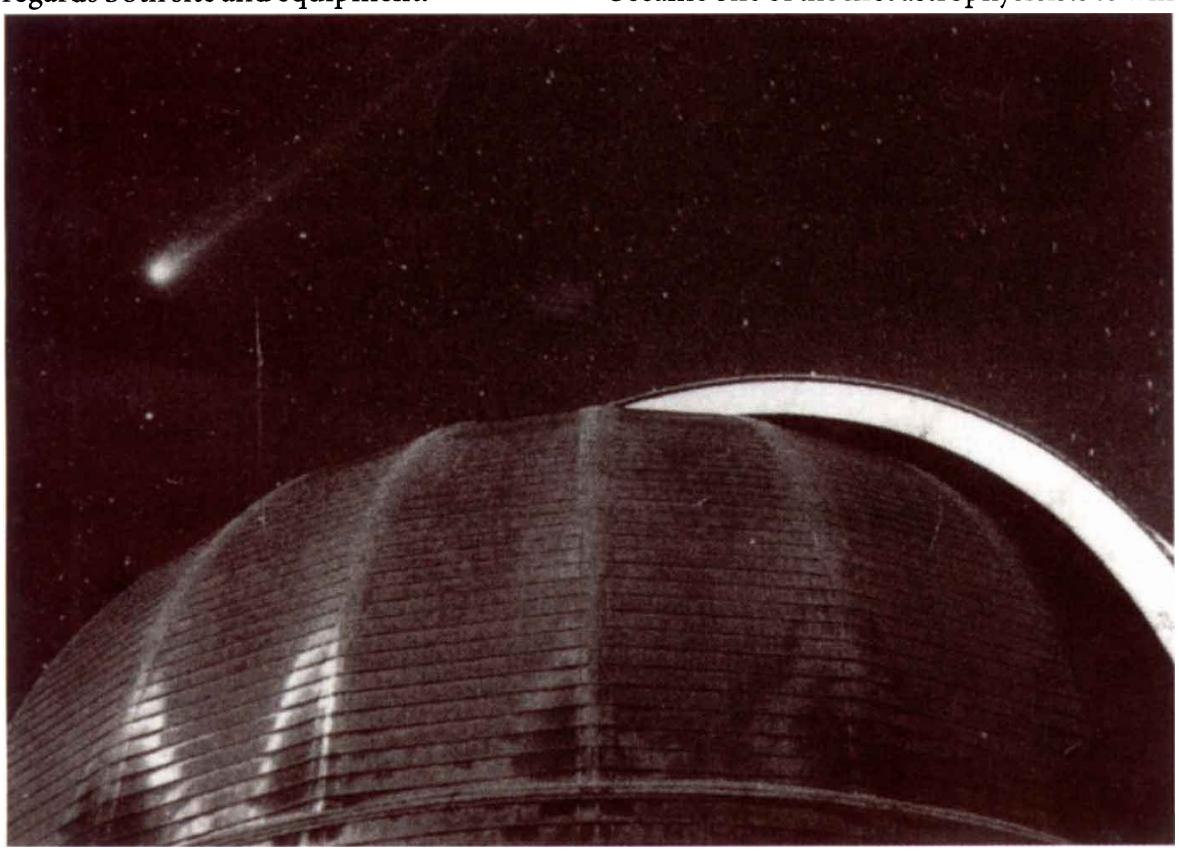

Country air, clear skies: comet Hyakutake over the Yerkes Great Dome. a Nobel prize. But, when increasing tension led to Struve's departure from Yerkes in 1950 , it was a sign that the golden years were over. Although good work remained to be done, the observatory has never reached the same heights since.

This is an excellent description of the ups and downs of a major observatory, told by someone who himself directed another leading US observatory - Lick in California. My only criticism is that few of the stories with which Yerkes staff entertained visitors are mentioned. What about the gargoyle of Charles Yerkes that is supposed to have been carved on the building, or the photographic plate with a bullet-hole through it from the Chicago gang wars?

Jack Meadows is in the Department of Information and Library Studies, Loughborough University of Technology, Loughborough, Leicestershire LE11 3TU, UK.

\section{The erotic ape}

\section{Bonobo: The Forgotten Ape}

by Frans de Waal and Frans Lanting

University of California Press: 1997. Pp. 210. $\$ 39.95$

\section{William McGrew}

Apart from ourselves, there are only four living species of great apes, and three of these are well-known to Western science, largely through the efforts of Louis Leakey's protégées: Jane Goodall on chimpanzees (Pan troglodytes), Dian Fossey on mountain gorillas (Gorilla gorilla) and Biruté Galdikas on orangutans (Pongo pygmaeus). The fourth species, Pan paniscus, the bonobo or pygmy chimpanzee, remains relatively obscure. It is arguably better known to Eastern science, with two of the previous three books on the species coming from Japanese primatologists (Takayoshi Kano, The Last Ape, 1986 \& 1992; Suehisa Kuroda, The Unknown Ape, 1982).

Now, finally, comes a synthesis of what is known about bonobo behaviour in captivity and in nature, by a pair of Dutchmen, laboratory ethologist Frans de Waal and wildlife photographer Frans Lanting. De Waal provided the text and notes, while Lanting journeyed to Zaïre to photograph the apes of Wamba. The result is a handsome, semicoffee table volume with more than 70 colour plates; yet with an extensive bibliography and nine pages of detailed notes. The text is crisp and clean, enlivened by de Waal's gently ironic humour, which readers of his previous books, Chimpanzee Politics (1982), Peacemaking among Primates (1989) and Good Natured (1996), have come to expect.

The bonobo is not so much the forgotten ape as the ape yet to be studied. Discovered by science little more than 60 years ago, the species lives naturally only in remote areas of 